\title{
CARBON MONOXIDE EMISSIONS OF COMBINED PELLET AND SOLAR HEATING SYSTEMS
}

\author{
Frank Fiedler, Tomas Persson \\ Solar Energy Research Center SERC, \\ Dalarna University College, S-78188 Borlänge, \\ Phone: +46 (0) 237787 11, Fax +46 (0) 237787 01, ffi@du.se
}

\begin{abstract}
Emissions are an important aspect of a pellet heating system. Low harmful emissions, particularly carbon monoxide, are a measure of a well performing system. High carbon monoxide emissions are often caused by unnecessary cycling of the burner when the burner is operated below the lowest combustion power. Combining pellet heaters with a solar heating systems can significantly reduce cycling of the pellet heater and avoid the inefficient summer operation of the pellet heater.

Five combined systems representing the range of typical solutions of this system type and one recently developed system have been studied, modelled and simulated. These systems are compared to a reference system which is based on a pellet boiler and is not combined with a solar heating system.

The aim was to study CO-emissions of the different types of systems and to analyse the potential of CO-emission reduction when the pellet heater is combined with a solar heating systems. Another aim was to compare the yearly CO-emissions obtained from simulations under realistic dynamic conditions with the yearly CO-emissions calculated based on the values that are obtained by the standard test methods.

The study was performed with the simulation tool TRNSYS. The parameter used in the study have been identified from lab measurements on existing pellet boilers/stoves and solar heating systems. The results from the simulations show that is possible to almost halve the CO-emission if the pellet heater is combined with a solar heating system. The results also show that the CO-emission of existing combined solar and pellet heating systems can be drastically reduced if the pellet heater is properly controlled and some basic design rules are observed. This can also be seen when analyzing the results for the new system concept where these rules have been taken into account. Comparing the yearly CO-emissions obtained from the simulations with the yearly CO-emissions calculated based on the standard test methods shows that using the latter give too low CO-values for the whole year. It is also shown that for the existing systems the average emissions under these realistic annual conditions were greater than the limit values of two Eco-labels.
\end{abstract}

Keywords: Carbon monoxide emissions, Pellet and solar heating systems.

\section{INTRODUCTION}

More than half of the Swedish population lives in detached houses (SCB, 2006). Almost 1.6 million detached houses are in use of which about one third is heated directly with electricity (SCB, 2005). The dramatically increased prices for oil and electricity over the last few years encourage many house owners with electric heating or and oil heating systems to convert their heating systems. Today mainly heat pumps are installed but also pellet heating systems get more and popular. In 2006 about 11500 new pellet heating systems have been installed (SBBA, 2005). The largest markets for pellet boilers are in Sweden, Austria and Germany. In Italy about 125000 pellet stoves have been installed by 2004 (Pelletcentre, 2007). In Sweden pellet stoves, pellet boilers and pellet burners are marketed. The latter is very popular non-expensive measure to convert oil boilers to pellet boilers by only replacing the burner.

Studies have shown that the combination of conventional boiler heating systems with solar heating is beneficial in terms of fuel savings and lower emissions since the boiler usually in the summer can be turned off when it's efficiency is low (Lorenz et al., 2003, Thür et al., 2004). This has also been confirmed for a heating system based on a pellet boiler (Persson et al., 2006b). A combination with a solar heating system is also attractive for systems based on a water mantled pellet stove. Usually the stove needs to be turned off outside the heating season to prevent overheating in the building. During this time the solar system provides the heat for the domestic hot water (DHW).

Emissions of harmful gases are important in addition to the efficiency and the thermal performance of pellet heating units. The national building codes and emission regulations include limits of allowable emissions of noxious gases for wood pellet boilers (SIS, 1999, Boverket, 2006). More stringent limit values are applied by the Swedish Testing Institute (SP) and eco-labels such as the Svanmark (SP, 1999, Nordic-Ecolabelling, 2006b). The limit values can be expected to further sharpened when comparing the limit values from other European regulations and eco-labels (RAL, 2003a, 2003b, BAFA, 2007). More stringent limit values have also been proposed by the Nordic eco-label Svanmark (Nordic-Ecolabelling, 2006a). In Table 1 the official limit values for emissions and efficiencies for pellet boilers and pellet stoves are compared with the current limit values from eco-labels and other regulations in Sweden and Germany. 
Table 1. Limit values for emissions from automatic fed pellet heating units with a nominal combustion power smaller than $50 \mathrm{~kW}$, CO- carbon monoxide, OGC-organic gaseous carbon (RAL, 2003a, 2003b, Pettersson, 2005, Nordic-Ecolabelling, 2006a).

\begin{tabular}{|c|c|c|c|c|c|c|}
\hline \multirow{3}{*}{\multicolumn{2}{|c|}{ Regulation }} & \multirow{3}{*}{$\begin{array}{c}\text { Boiler efficiency } \\
\%\end{array}$} & \multicolumn{4}{|c|}{ Limit value for emission } \\
\hline & & & NOx & $\mathrm{CO}$ & OGC & Particles \\
\hline & & & \multicolumn{4}{|c|}{$\begin{array}{l}\mathrm{mg} / \mathrm{m}^{3} \text { dry flue gas with } 10 \text { vol- } \% \mathrm{O}_{2}, 0^{\circ} \mathrm{C} \\
1013 \text { mbar }\end{array}$} \\
\hline \multicolumn{2}{|c|}{$\begin{array}{l}\text { EN 303-5 } \\
\text { (class 3) }\end{array}$} & $67+6 \log P_{N}$ & - & 3000 & 100 & 150 \\
\hline \multicolumn{2}{|c|}{$\begin{array}{l}\text { SP-Swedish testing institute, } \\
\text { P-mark }\end{array}$} & 80 & - & 2000 & 75 & - \\
\hline \multicolumn{2}{|c|}{ Nordic Ecolabelling, Svan-mark } & $72+6 \log P_{N}$ & - & 1000 & 70 & 70 \\
\hline \multicolumn{2}{|c|}{$\begin{array}{l}\text { Nordic Ecolabelling, Svan-mark, } \\
\text { proposed } 2006\end{array}$} & $75+6 \log P_{N}$ & 340 & 400 & 25 & 40 \\
\hline \multirow{2}{*}{ Blauer Engel $^{1}$} & Pellet stoves & $\begin{array}{l}90 \text { at } P_{N} \\
88 \text { at } P_{\min }\end{array}$ & 150 & $\begin{array}{l}200 \text { at } P_{N} \\
400 \text { at } P_{\text {min }}\end{array}$ & $\begin{array}{l}10 \text { at } P_{N} \\
15 \text { at } P_{\min }\end{array}$ & 35 at $\mathrm{P}_{\mathrm{N}}$ \\
\hline & Pellet boiler & $\begin{array}{l}90 \text { at } P_{N} \\
\text { and } P_{\min }\end{array}$ & 150 & $\begin{array}{l}100 \text { at } P_{N} \\
300 \text { at } P_{\min }\end{array}$ & $\begin{array}{l}5 \text { at } P_{N} \\
\text { and } P_{\min }\end{array}$ & 30 at $P_{N}$ \\
\hline
\end{tabular}

In this study the emphasis has been on CO-emissions released from different pellet heating systems with different operating strategies combined or not combined with a solar heating system. CO-emissions from pellet stoves/boilers are highest during the start and stop phase (Figure 1). By operating the burner with modulating combustion power the number of starts and stops and consequently the start/stop CO-emissions can be reduced. On the other hand, the longer operation time leads to higher total CO-emissions during normal combustion. Both these effects are simulated in this study, and results are given for complete annual simulations with sub-hourly time step.

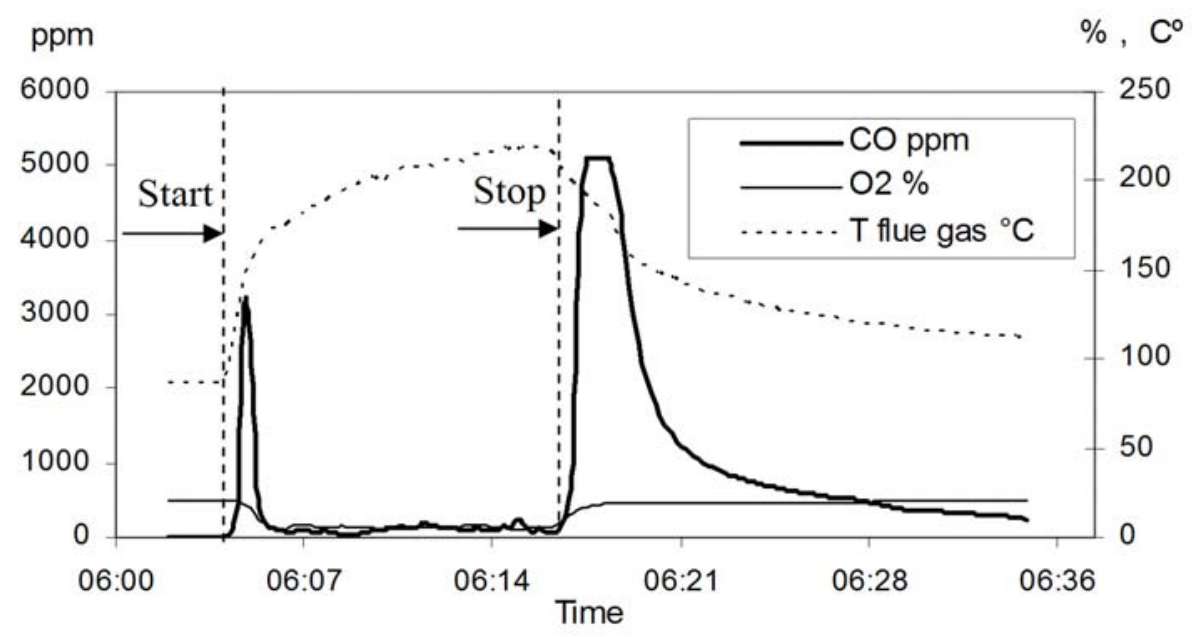

Fig. 1. CO-emissions of a pellets burner during a typical start/operation/stop sequence.

Previous simulation work by Persson (2004) and Persson et al. (2005) investigated the possibilities for replacing direct electric heating in single family houses with pellet stoves and solar heating systems for a variety of types of houses. Persson showed that modulating operation of the pellet stoves improves the thermal performance and decreases the CO-emissions. Simulation studies performed by Fiedler (2006) compare typical commercial systems in terms of heat losses, thermal performance and CO-emissions. Persson et al. (2006b) show for one system that the combination of a pellet boiler with a solar heating system can reduce the pellet consumption by $25 \%$ and the COemissions by $44 \%$. If the system is properly designed and well insulated the energy savings can be higher than the solar gains since the low efficiency operation of the boiler during summer can be reduced. Another work on this type of systems by Fiedler et al. (2006) proposed an optimization method for the design of combined pellets and solar heating systems. For one example system with a pellet boiler he shows that optimising the system for low emissions and low fuel consumption leads to different design parameters. However, design parameter with good results for both objectives could be found.

In this study simulation results for the CO-emissions of in total six combined solar and pellet heating have been compared and analyzed. The first four systems represent the variety of system types that are available today in Sweden. The results have been compared with the simulation results from the boiler system studied by Persson et al. (2006b) and the simulation results from a new system concept of a combined solar and pellet heating system. This 
system has been developed within the Nordic research project REBUS (Bales et al., 2004, Furbo et al., 2006) and is described in detail in (Fiedler, 2006).

\section{METHOD}

This work compares and analyses the simulation results of six combined solar and pellet heating systems that have been chosen from a variety of design variants. Four of them were chosen to represent the range of commercially available solutions found in Sweden. The systems contain: a water mantled stove; an air cooled pellet stove; a store integrated pellet burner; and a standalone pellet boiler. The fifth system is similar to the system with the standalone boiler but uses a boiler with an adequate size of $12 \mathrm{~kW}$. The sixth system is based on a completely new system concept using a very efficient Austrian pellet boiler. The pellet heating units in these systems had been previously tested at the Solar Energy Research Center, Borlänge (Persson et al., 2006a). The systems were modelled in the simulation environment IISiBat/TRNSYS (Klein et al., 2005) based on a system simulation model created for IEASHC Task 26 Solar Combisystems (Bales, 2003). The house model SFH60 from Task 26 (Streicher et al., 2003) and other standard boundary conditions for climate, and hot water load were applied.

The results from comprehensive measurements on the pellet stoves, pellet boilers and storage tanks at the Solar Energy Research Center, Borlänge (Bales, 2004, Persson et al., 2006a) as well as specifications from the manufacturers were used to derive input parameter for the TRNSYS component models. For the collector, the parameter values from IEA-SHC Task 26 were used (Weiss, 2003).

The systems have been simulated for one year for the same boundary conditions for climate, in this study Stockholm (METEONORM, 1999), the domestic hot water (DHW) load and the space heating demand. Particularly design parameter such as the boiler combustion control and the boiler buffer volume have been varied to study the effect on the CO-emissions of the systems. For comparison two systems have also been simulated with only the boiler stove as main heat source and without solar heating system.

\section{STUDIED SYSTEMS}

Six combined solar and pellet heating systems were investigated (Figure 2). Two systems pellet stoves, one air cooled (system 1) and one with a water mantle in addition to being air cooled (system 2). System 3 has a store integrated pellet burner and system 4, 5 and 6 have a separate pellet boiler and store. Systems 1 and 2 have separated space heating (pellet stoves) and solar hot water systems with electric auxiliary heating. Systems $3,4,5$ and 6 are solar combisystems with pellet auxiliary heaters. The system designs that have been simulated in this study are all available on the Swedish market, with pellet heaters that are sold there, except system 6.

System 1 is the simplest system using separate units to provide domestic hot water and space heating. A pellet stove transfers the heat to the building by convection and radiation. This requires a building with open interior design in order to allow a good heat distribution to the building. The power of the stove is automatically and continuously modulated according to the room temperature, but has a limiting minimal power. In the specified power operation range between 2 and $6 \mathrm{~kW}$ the stove reaches efficiencies between 83 and $89 \%$ under stationary conditions (Persson, 2004 and 2006b). The domestic hot water is provided by a solar hot water system comprising a 320 I store and $5 \mathrm{~m}^{2}$ of solar collectors. The solar circuit is coupled to the storage by a heat exchanger immersed in the bottom of the store. The auxiliary heat is provided by an electric heater in the top third of the store.

System 2 is rather similar to system 1 but the pellet stove delivers heat to the building in two ways: directly by convection and radiation as in system 1; and indirectly through an inbuilt heat exchanger (water mantle) to the water based radiator system. Approximately $80 \%$ of the heat produced can be transferred to the radiator system when the stove is operated under stationary conditions with the maximum combustion power (Persson, 2004 and 2006b). The stove is on/off controlled by the room temperature, operating by default with the maximum power.

System 3 is a solar combisystem with a store integrated pellet burner and a water based radiator system. All required heat for hot water and space heating is taken from the combistore, the water for space heating directly and the domestic hot water by two immersed heat exchangers placed in the bottom and the top of the combistore. The heat from the solar heating circuit is transferred by another immersed heat exchanger in the bottom of the store. The store integrated pellet burner delivers heat by a gas to liquid heat exchanger consisting of horizontal pipes in the upper part of the store. The burner is on/off controlled by a sensor placed in the storage tank above the burner. The pellet burner has a maximum power of $25 \mathrm{~kW}$, enough capacity for single family houses with a high space heating demand. The burner can be adjusted for summer operation to half of the maximum combustion power, and this is what was used in this study $(12 \mathrm{~kW})$. The solar collector area for systems 3 and 4 is $10 \mathrm{~m}^{2}$ which is typical for Swedish solar combisystems.

System 4 is also a combisystem but uses a separate pellet boiler as the main auxiliary heat source. The pellet boiler is coupled to the upper part of the store and has an internal water volume of 140 litres. The on/off-controlled boiler contains integrated heat exchangers for hot water preparation, which is common in Swedish boilers, but this was not used in the system. No connections are available to couple the boiler to a solar circuit. Consequently only the space heating part of the boiler was used and connected to a combistore.

System 5 is very similar to system 4 and has been used in the simulation study of Persson et al. (2006b). The main difference is the usage of a 4-way for the radiator circuit and the usage of a $12 \mathrm{~kW}$ pellet boiler with a internal water volume of 50 litre. 
System 6 is a combisystems that has recently been developed. It consists of two units; the solar store unit and the technical unit that contains the hydraulic components including the pellet boiler and an auxiliary store for the hot water production. A detailed description can be found in (Fiedler, 2006). The system used an prototype of an Austrian $12 \mathrm{~kW}$ pellet boiler with an internal water volume of 20 litre. The boiler heats the auxiliary store and the upper part of the solar combi-store. The solar system can provide heat to both stores.

More details of the studied systems can be seen in Table 2.
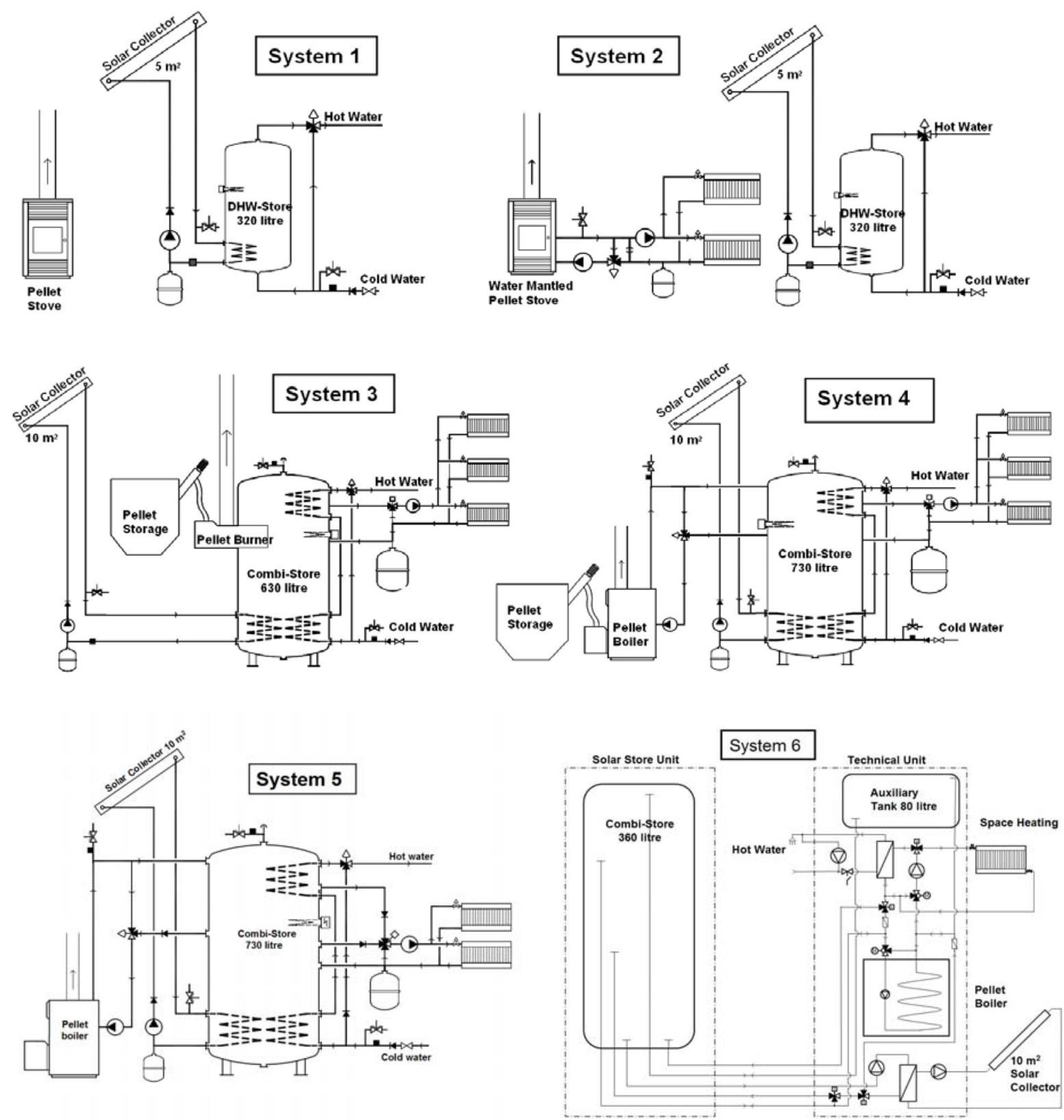

Fig. 2. Investigated system designs. Two systems with a pellet stove (system 1 and 2), one with a store integrated pellet burner (system 3) and one with a pellet boiler (system 4, 5 and 6). 
Table 2. Overview main system size parameter.

\begin{tabular}{|c|c|c|c|c|c|c|c|}
\hline & System 1 & System 2 & System 3 & System 4 & System 5 & System 6 & Unit \\
\hline Max./min. power pellet heater & $6 / 2$ & $11.6 / 2$ & $12^{1} / 8.1$ & $20 / 7.8$ & $12.5 / 4.5$ & $12 / 3.4$ & kW \\
\hline $\begin{array}{l}\text { Start temperature pellet heater } \\
\text { (for stoves the room temperature } \\
\text { for the boilers the store temperature) }\end{array}$ & 19 & 19 & 65 & 60 & 61 & 60 & ${ }^{\circ} \mathrm{C}$ \\
\hline dT for heater start and stop & 1.2 & 2 & 20 & 15 & 10 & 15 & $\mathrm{~K}$ \\
\hline CO-emission during start phase & 0.5 & 2 & 1.2 & 1 & 2.2 & 4.4 & $\mathrm{~g} /$ start \\
\hline CO-emission during stop phase & 1.35 & 1.2 & 6.4 & $6^{1}$ & $21^{2}$ & 1.4 & g/stop \\
\hline Internal water volume boiler & - & 0.04 & - & 0.14 & 0.05 & 0.02 & $\mathrm{~m}^{3}$ \\
\hline Collector area & 5 & 5 & 10 & 10 & 10 & 10 & $\mathrm{~m}^{2}$ \\
\hline DHW/combi store size & 0.320 & 0.320 & 0.631 & 0.729 & 0.729 & $\begin{array}{c}0.360 \\
(+0.08)\end{array}$ & $\mathrm{m}^{3}$ \\
\hline Auxiliary volume pellet heater & - & - & 0.265 & 0.286 & 0.197 & 0.140 & $\mathrm{~m}^{3}$ \\
\hline
\end{tabular}

${ }_{1}$ The boiler emits additional $3 \mathrm{~g}$ CO per hour if kept in standby mode.

2 Value is smaller if the stop phase is interrupted early by a new start phase.

\section{MODELLING IN TRNSYS}

The modelling of the systems in TRNSYS is based on the system models and boundary conditions used in IEA-SHC Task 26 Solar Combisystems (Bales, 2003), which includes both the building (single node in type 56) and heat distribution using a radiator and PID controller modelling the thermostatic valve. For the system with air cooled pellet stove, no radiator was used. The boundary conditions for the systems are defined by the climate, in this study Stockholm (METEONORM, 1999), the domestic hot water (DHW) load and the space heating demand. The DHW load has been modelled with a load profile developed by (Jordan et al., 2002) assuming a daily hot water demand of about 200 litre ( $3100 \mathrm{kWh} / \mathrm{year})$. The space heating demand is modelled by an one zone building model developed for IEA-SHC task 26 giving a yearly heat demand of approximately $12200 \mathrm{kWh}\left(87 \mathrm{kWh} / \mathrm{m}^{2}\right)$ for Stockholm.

The one zone building model assumes perfect heat transfer from the stove in system 1 to the whole building without using a separate heat distribution system. This is a simplification and equates to a house with a very open plan layout. The collector is modelled using type 132, with the parameters used in IEA-SHC Task 26, equating to a good quality glazed flat plate collector with selective absorber.

All DHW-stores and combistores have been modelled with TRNSYS type 140 (Drück, 1996). The parameters for these were identified from measurements in the lab (systems 3, 4, 5 and 6) or derived from manufacturers data (systems 1 and 2). The losses from the store and, in the case of system 3 and system 4, also from the boiler, are not used as heat input to the building model and are considered as waste heat.

Modelling of pellet stoves, burner and boiler were implemented with TRNSYS-component type 210 (Nordlander, 2003, Nordlander et al., 2006). This dynamic model can be used to simulate pellet stoves, pellet burners and pellet boilers and gives flue gas losses during operation and in standby mode (leakage losses), as well as heat supplied to water in a mantle and to the surroundings. The model also calculates the CO-content in the flue gas, including the emissions during the start and stop phases. The parameter values used in this study were derived from parameter identification using measured data from the stoves/boilers, and have been verified against measured data (Fiedler, 2006, Persson et al., 2006a). The parameter values for each of the pellet heaters used to simulate the CO-emissions of the pellet heaters can be seen in Figure 3. The CO-emissions calculated by the model are based on measured data from each pellet heater. The model calculates the CO-emissions as the sum of a power dependent part during normal operation and a lumped constant amount per start and stop. The total cumulated emissions for the whole simulation are calculated with Eq. (1):

$\mathrm{m}_{\text {COcum }}=\mathrm{N}_{\text {stacum }} \cdot\left(\mathrm{m}_{\text {COsta }}+\mathrm{m}_{\text {COstp }}\right)+\mathrm{Q}_{\mathrm{fcum}} \cdot\left(\mathrm{D}_{\mathrm{CO} 0}+\mathrm{D}_{\mathrm{CO} 1} \cdot \frac{\mathrm{P}_{\mathrm{CAW}}}{\mathrm{P}_{\max }}\right)$ 


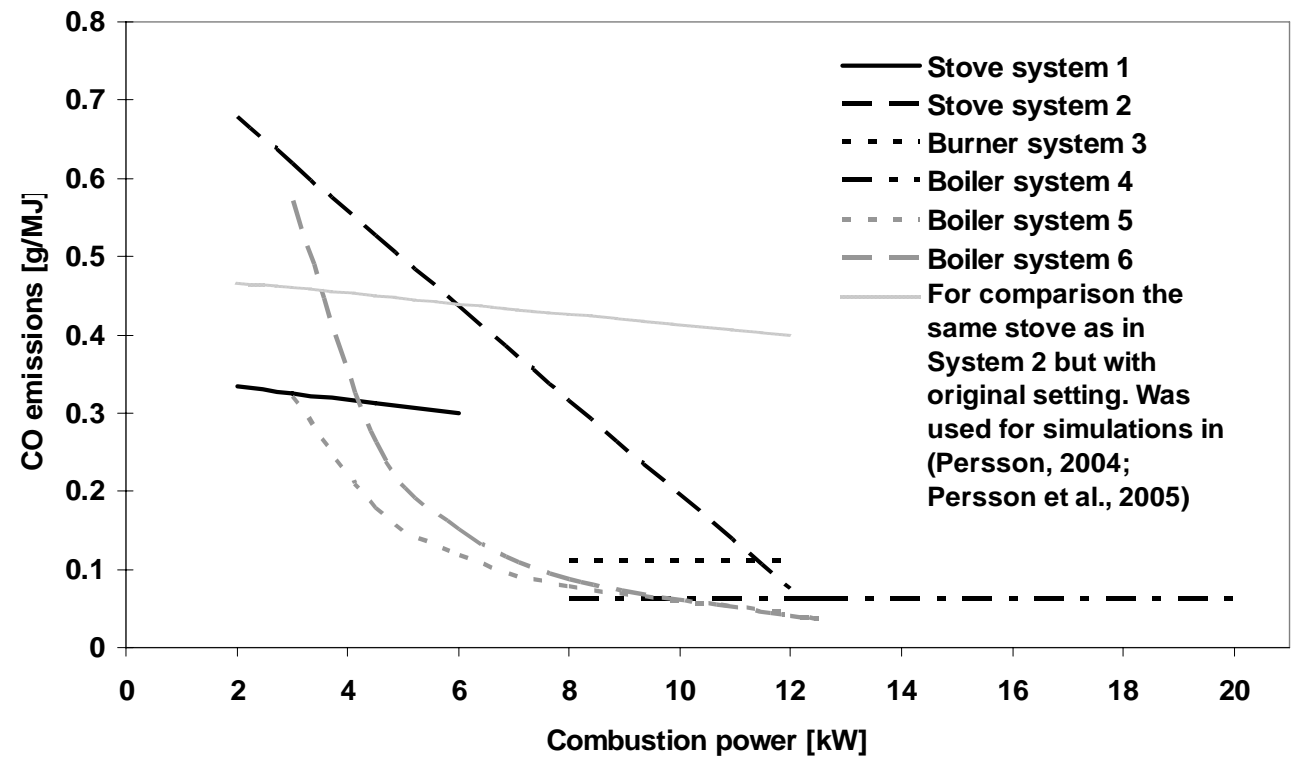

Fig. 3. CO-emissions in g per MJ pellets of the six pellet heating units.

The systems have been simulated as described in section "Studied Systems" hydraulically connected as in Figure 2 using the parameter values in Table 2 and Figure 3. Two variants of operating strategy were chosen for simulations of each system. On/off control using the full power of the heaters and modulation control was used with the measured modulation range for the specific heaters simulated in the systems. In addition, a parametric study has been performed for system 6. The aim was to study the impact of the boiler buffer volume on the CO-emissions. For comparison, system 5 and 6 have also been simulated with only the boiler or stove as main heat source and without solar heating system (solar collector loop and combistore).

The most important simplification in this simulation study was the use of a single node building model. For the stove systems, this means that in the model the convective and radiative heat is transferred to the whole building and not only to the room where the stove is placed. This equates to a building with perfect heat transfer between rooms. Additionally the heat losses from the boiler systems were not given as inputs to the building model. This is the case if they were placed in a cellar.

In all simulations the pellet heaters have been operated during the space heating season only, and have been turned off during the summer months. An electric backup heater has been used as auxiliary outside of the space heating season.

\section{RESULTS}

Figure 4 shows the CO-emissions for the six systems in $\mathrm{kg}$ divided in start/stop emissions, emissions during operation and standby emissions. The latter occur only for the boiler in system 4 which has an option to operate in a standby mode when there is no heat demand. Keeping the boiler in this standby mode (by constantly combusting a little amount of pellet) increases the CO-emissions dramatically. The assumption here is that the start emissions are the same as if the boiler would not kept in standby. This has not been investigated in detail and the standby operation has not been included in the system simulations. Instead, the standby emissions in Figure 4 have been determined by separate calculations based on measurement of the boiler during standby operation.

From Figure 4 it can bee seen that the amount of emitted CO varies significantly for the different systems. The boiler systems have large start/stop emissions whereas the start/stop emissions for the stove systems are very low. The pellet stove in system 2 emits with $7 \mathrm{~kg}$ in on/off mode the lowest amount of CO per year whereas the boiler in system 5 emits $37 \mathrm{~kg} \mathrm{CO}$ per year if on/off operated. The stove systems (system 1 and 2) emit most CO during operation whereas the combisystems (system 3-6) emit most CO during start and stop when on/off operated. For system 3, 4, 5 and 6 the start/stop emissions decreases drastically if controlled with modulating power. The COemissions of system 2 are much higher when operated with modulating power. The CO-emissions for system 1 are almost the same regardless if the stove is operated with on/off and modulating combustion power. 


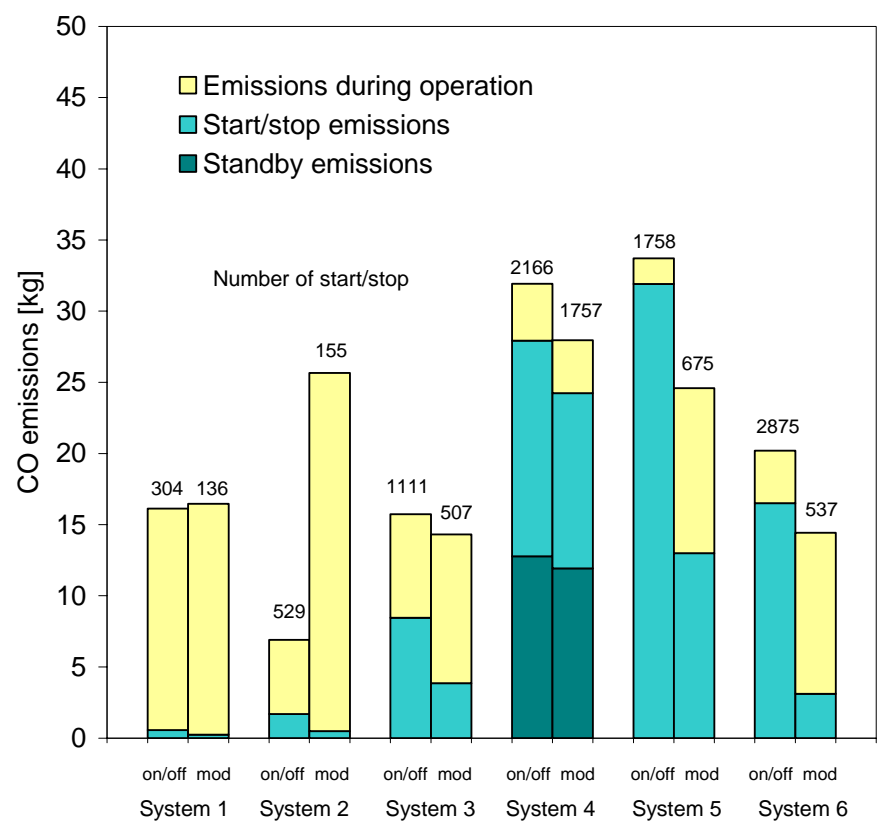

Fig. 4. CO-emissions for start/stop, normal operation and standby of the pellet heaters in the systems for on/off and modulating operation.

The pellet consumption is not the same for all systems. For a qualitative comparison of the CO-emissions for the different system it is therefore necessary to express the CO-emissions in a specific form, in kg per MJ pellet (Figure 5). Together with the specific emissions of each system the limit values for $C O$ from two eco-labels are indicated. The relative high limit value of the Standard EN 303-5 of $13214 \mathrm{mg} / \mathrm{MJ}$ is not indicated. It can be seen that only system 2 , if on/off controlled, would fulfill the recently proposed limit values for the Svan-mark if the start and stop emissions and realistic conditions are taken into account. None of the stoves and boilers would fulfill the requirements for the Blauer Engel-mark. The dashed area shows the emissions of the stoves and boilers from lab measurements at constant nominal combustion power. These are much lower than the average annual emissions except for the stove in system 1 that has very little start and stop emissions. Note that for system 4 only the emissions for start/stop and normal operation are included but not the emissions for standby. These emissions have been excluded because no measurement data for the pellet consumption during standby were available.

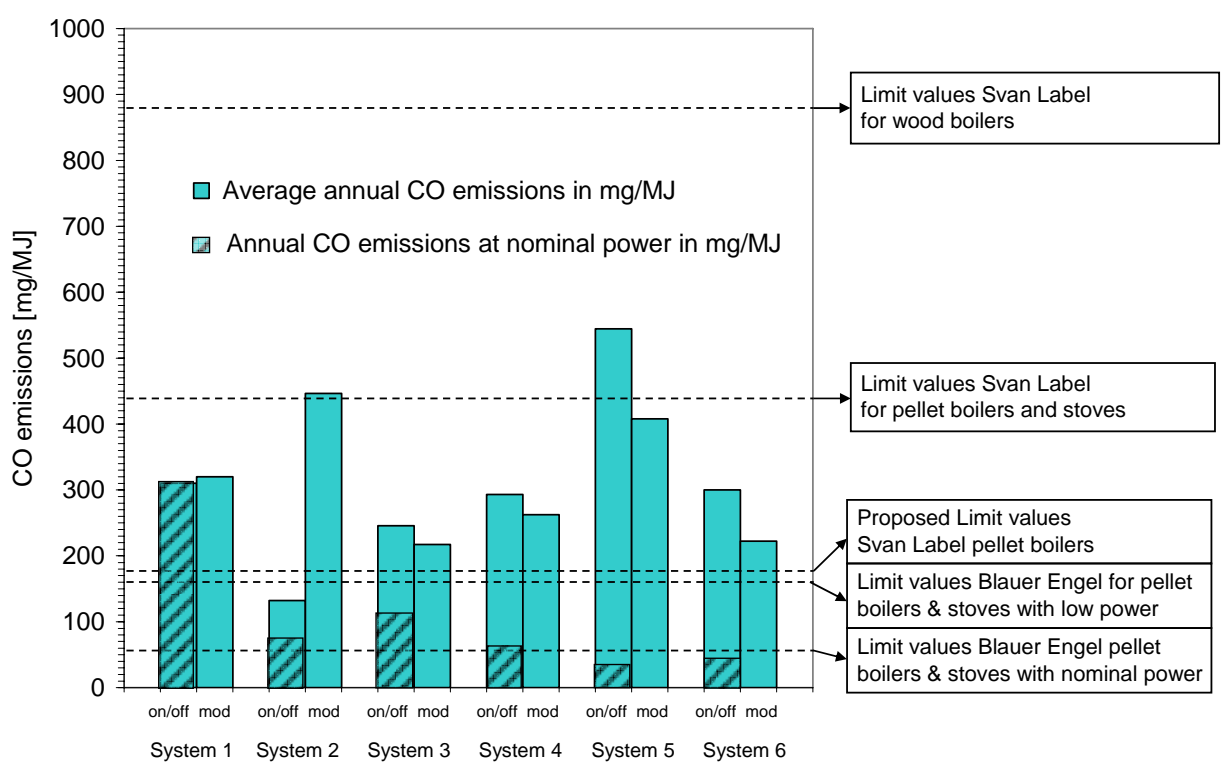

Fig. 5. Average annual CO-emissions in mg per MJ pellet in in comparison with limit values of the Eco-labels Svan-mark and Blauer Engel-mark according Nordic-Ecolabelling (2006). 
In Figure 6 the annual CO-emissions of the pellet boiler used in system 5 from (Persson et al., 2006b), with and without solar heating system, and the CO-emission of system 6 (with a solar heating system) are compared. The boiler in system 6 uses a buffer volume of 140 litre. It can be seen that the CO-emissions for system 5 can be reduced by almost the half by adding a solar system. This is mainly due to the reduction of the number of starts and stops from 3352 (on/off controlled) and 1601 (modulating power) to 1758 (on/off controlled) and 675 (modulating power). For system 6 , that uses an Austrian pellet boiler with relatively low start/stop emissions, the annual COemissions would be only a third of the boiler used in system 5.

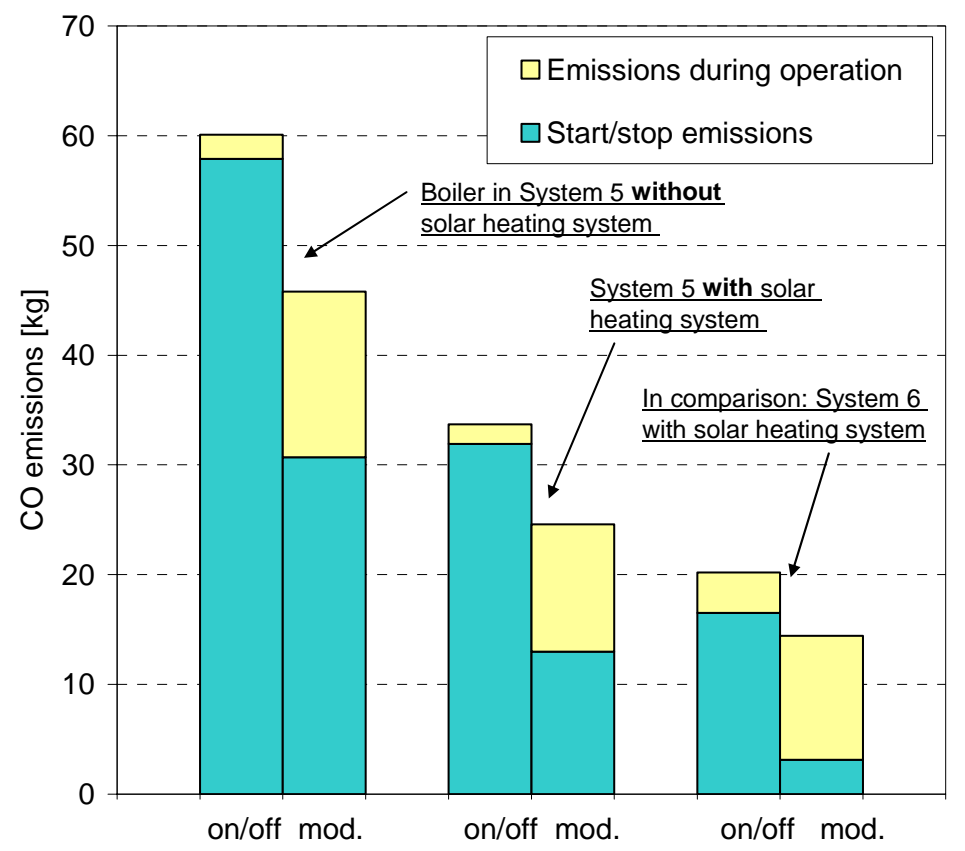

Fig. 6. Average annual CO-emissions in $\mathrm{kg}$ for system 5 including and not including a solar heating system and system 6 with a solar heating system and 140 liter buffer volume for the pellet boiler.

Figure 7 shows the result of a parametric simulation study of system 6 . The parameter varied was the size of the buffer volume available for the pellet boiler. As a reference the system was simulated without a solar system and with only a minimum buffer volume for the pellet heater. This minimum buffer volume is the 80 litre auxiliary tank that can be seen in Figure 2. The buffer volume is then further increased by using a part of the upper combistore which in turn reduces the volume available volume for the solar collectors.

Also here can bee seen that the CO-emissions are significantly reduced by combining the pellet heating system with a solar heating system. However, the reduction is smaller as for system 5 with about 20\%. Changing the boiler control for system 6 to modulating power gives between $26 \%$ and $32 \%$ lower CO-emissions.

In order to achieve lowest CO-emissions the buffer volume for the boiler should be about 140 litre. A larger volume does not lead to a significant decrease in CO-emissions even if the number of start/stops can be further reduced. Instead the heat losses increase with the larger buffer volume and the primary energy use is increasing (Figure 8a). 


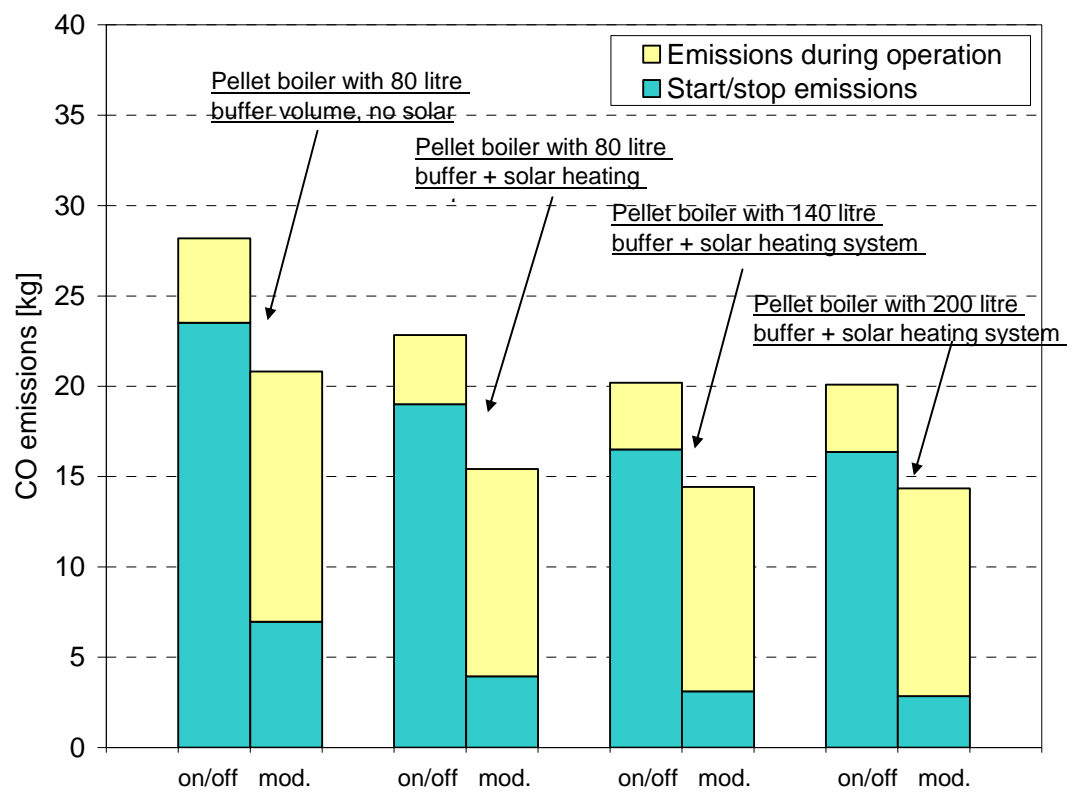

Fig. 7. Annual CO-emissions from a parametric study of the boiler buffer store volume for system 6 with on/off and modulating combustion control. In the first two columns the heat for system was for the whole year solely provided by the pellet boiler.

The energy savings by combining the boiler system with and solar heating system are for all studied buffer sizes greater than the solar gains (Table 3). This is due to the poor efficiency of the pellet boiler with low load mainly during the summer months (Figure 8b). During this time the solar heating system covers the heat demand and increases by that the energy savings up to $7.5 \%$ for on/off control and up to $4.2 \%$ for modulating combustion control.

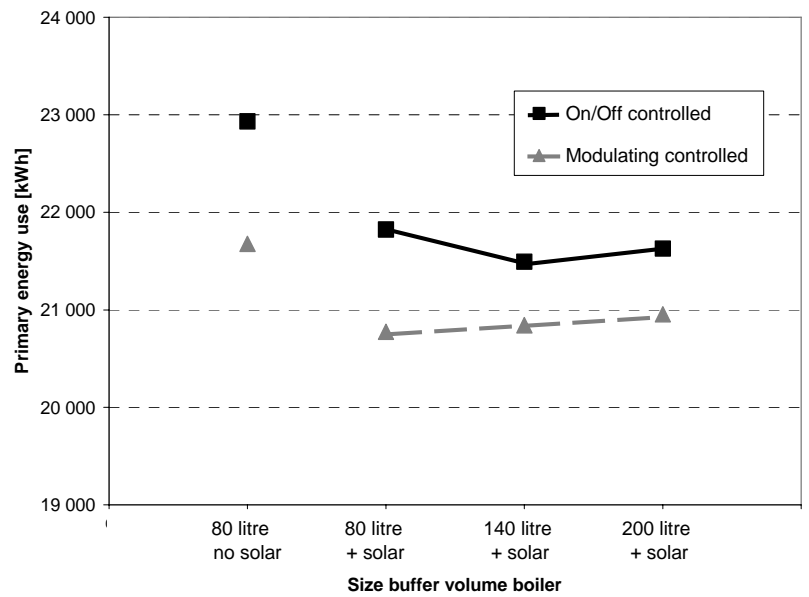

(a)

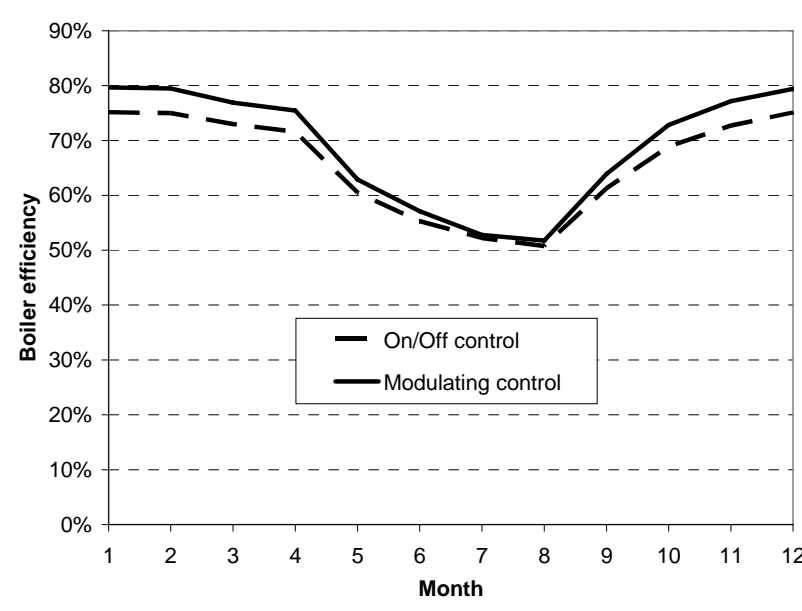

(b)

Figure 8. Primary energy use of system 6 for parametric study of the boiler buffer volume for on/off and modulating combustion control (a). Monthly average efficiency of the pellet boiler in system 6 for on/off and modulating combustion control (b). 
Table 3. Primary energy usage, number of starts/stops, solar gains and saving for parametric study of system 6 .

\begin{tabular}{|c|c|c|c|c|c|c|c|c|}
\hline & \multicolumn{2}{|c|}{ Reference (no solar) } & \multicolumn{2}{|c|}{80 liter buffer + solar } & \multicolumn{2}{|c|}{140 liter buffer + solar } & \multicolumn{2}{|c|}{200 liter buffer + solar } \\
\hline & On/off & Mod. & On/off & Mod. & On/off & Mod. & On/off & Mod. \\
\hline $\begin{array}{l}\text { Pellet consumption } \\
\text { [kWh] }\end{array}$ & 22888 & 21473 & 18805 & 17682 & 18692 & 18023 & 18934 & 18240 \\
\hline $\begin{array}{l}\text { Number of } \\
\text { start/stops }\end{array}$ & 4054 & 1201 & 3277 & 680 & 2845 & 537 & 2822 & 490 \\
\hline Solar gain [kWh] & - & - & 3015 & 3050 & 2802 & 2820 & 2693 & 2714 \\
\hline $\begin{array}{l}\text { Fuel saving } \\
\text { compared to } \\
\text { reference [kWh] }\end{array}$ & - & - & 4083 & 3791 & 4196 & 3450 & 3954 & 3233 \\
\hline Fuel savings [\%] & - & - & 18 & 18 & 18 & 16 & 17 & 15 \\
\hline
\end{tabular}

\section{DISCUSSION AND CONCLUSION}

Figure 4 and 5 showed that the amount of emitted $\mathrm{CO}$ varies significantly for the different systems. There are several reasons for these differences. Each pellet heater has its own CO-characteristic for the operation with a particular combustion power (Figure 3) and during start and stop (Table 2) The pellet heaters vary also in their nominal power from $6 \mathrm{~kW}$ to $20 \mathrm{~kW}$ which of course together with the size of the buffer volume, the boiler control mode and the way the heat is transferred to the building influence the number of starts and stops.

The boiler systems have large start/stop emissions whereas the start/stop emissions for the stove systems are very low. This is due to the much lower total number of starts and stops of the stoves using the complete building as heat storage. This is a simplification which provides that the heat can be freely distributed to the building. A more advanced multi zone building model for simulations of stove systems has been used by Persson. Perssons studies showed that stove systems have similar number of starts and stops as boiler systems if the convective and radiative part of the heat from the stoves can not be freely distributed to the complete building (see table 3.2 in (Persson, 2006)).

The CO values from system 4 show that operating a pellet boiler in standby increases the CO-emissions dramatically and should be prevented.

The stove systems emit relatively little CO during start/stop but relatively much $\mathrm{CO}$ during operation. For the boiler systems it is the other way round. The stop emissions are here particularly high for underfed boilers (system 4 and 6 ) where the pellets are fed from the bottom of the burner. When the boiler stops a large amount of pellet are smouldering in the burner and probably causing the high emissions during the stop phase.

The simulation results have shown that operating the boilers/stoves with modulating combustion power will not always lead to lower CO-emissions. As can be seen in Figure 5 for system 2 even the opposite effect might occur, which is contradictory to the simulation results from studies of (Persson, 2004, Persson et al., 2005). This can be explained by the different $\mathrm{CO}$ parameter used for the simulations. The parameters used for these simulations were obtained from measurements of the stove with the default air factor settings, whereas Persson used parameters that were obtained from measurements with in-situ adjusted combustion air settings (see Figure 3). This suggests that it is to be recommended that the air settings be adjusted by the installer at the installation site. The extremely low COemissions for system 2 for on/off control can easily be understood by the low emissions at full power (12 kW) and the relatively small number of starts/stops and their related emissions.

In Figure 5 the specific CO-emissions for each system are compared with the CO-limit values for two Eco-labels. All systems are below the rather high limit value of the Standard EN 303-5 of $1314 \mathrm{mg} / \mathrm{MJ}$ which is not indicated in this figure. However, it can be seen that only system 2, if on/off controlled, would fulfil the recently proposed limit values for the Svan-mark if the start and stop emissions and realistic conditions are taken into account. None of the stoves and boilers would fulfil the requirements for the Blauer Engel-mark. The dashed area shows the emissions of the stoves and boilers at nominal combustion power. In Figure 9 the specific CO-emissions for system 5 without solar are compared to the same limit values. In the same figure the CO-emissions of this boiler measured during nominal and minimal combustion power are shown. Testing institutes usually use a mixture of the measured CO-emissions at nominal and minimal load to specify CO-emissions of the tested pellet heater. The comparison shows that this leads to a drastic underestimation of the real annual CO-emissions due to the fact that the start/stop emissions are not included. This shows the limitation of the method using simple constant loads to determine the CO-emissions for pellet stoves and boilers, as used in the current norms and eco-labels, and suggests that they should be revised to include an estimation of total annual emissions based on the operation of the boiler and the average load. 


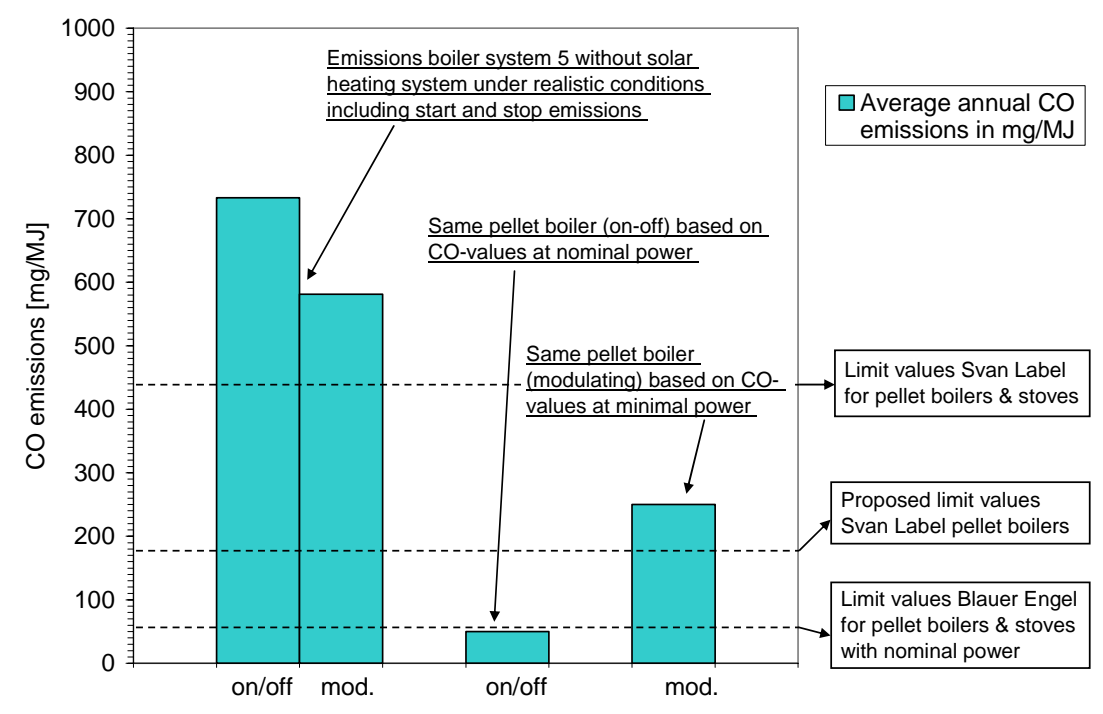

Fig. 9. Average annual CO-emissions in $\mathrm{kg}$ per MJ pellet for the pellet boiler in system 5 without solar system and specific CO-emissions of the same boiler obtained with nominal and minimal combustion power in comparison with limit values of the eco-labels Svan-mark and Blauer Engel-mark.

Combining solar and pellet heating systems can reduce significant CO-emissions compared to operating a single pellet heating system. This combination prevents the summer operation of the pellet heater with low efficiency and high emissions. In addition, the pellet heater can, if coupled to the solar combistore, heat a larger water volume resulting in a longer operation time with less start/stop emissions. Simulations for two systems (system 5 and 6 ) have shown that the CO-emissions for a solar combisystem can be $19 \%$ to $45 \%$ lower compared to a single pellet heating system using the same boiler.

\section{ACKNOWLEDGEMENT}

We are grateful to the Nordic Energy Research and the Dalarna University College for their financial support for this work within the REBUS project.

\section{NOMENCLATURE}

$\mathrm{m}_{\text {cocum }}$
$\mathrm{N}_{\text {stcum }}$
$\mathrm{m}_{\text {cOsta }}$
$\mathrm{m}_{\text {cOstp }}$
$\mathrm{Q}_{\text {fcum }}$
$\mathrm{D}_{\text {cO0 }}$
$\mathrm{D}_{\text {cO1 }}$
$\mathrm{P}_{\text {CAW }}$
$\mathrm{P}_{\text {max }}$

Cumulative amount of emitted CO [kg]

Cumulative number of starts

Mass of emitted CO during start [kg]

Mass of emitted CO during stop [kg]

Fuel combustion energy [MJ]

CO-emission factor, constant part $\left[\mathrm{g} / \mathrm{MJ}^{-1}\right]$

CO-emission factor, power dependent part $\left[\mathrm{g} \mathrm{MJ}^{-1}\right]$

Average power, energy weighted [MJ]

Maximal combustion power [MJ]

\section{REFERENCES}

BAFA, 2007, Richtlinien zur Förderung von Maßnahmen zur Nutzung erneuerbarer Energien vom 12. Januar 2007. Bundesamt für Wirtschaft und Ausfuhrkontrolle - Bundesministerium für Wirtschaft und Technologie (BMWi).

Bales C., 2003, Reports On Solar Combisystems Modelled in Task 26 (System Description, Modelling, Sensitivity, Optimisation), Appendix 6: Generic System \#11: Space Heating Store With DHW Load Side Heat Exchanger(S) And External Auxiliary Boiler. IEA-SHC Task 26 Solar Combisystems.

Bales C., 2004, Combitest - A New Test Method for Thermal Stores Used in Solar Combisystems. Doctoral Thesis. Chalmers University of Technology. Göteborg, Sweden. ISBN 91-7291-465-3.

Bales C. and S. Furbo, 2004, Heat in a cold climate: Solar heating systems developed for the Nordic market. Refocus 5, 2 : 32-34.

Boverket. Regelsamling för byggande, Boverkets byggregler, BBR, BFS 1993:57 med ändringar till och med 2006:12, Boverket, 2006. 91-7147-960-0.

Drück H., Pauschinger, T.,1996, TRNSYS Type 140, Multiport Store Model. ITW, University Stuttgart, Germany.

Fiedler F., 2006, Combined solar and pellet heating systems - Study of energy use and CO-emissions. PhD thesis. Mälardalen University. Västerås. 
Fiedler F., C. Bales, T. Persson and A. Thür, 2006, Design method for solar heating systems in combination with pellet boilers/stoves, EuroSun Conference, Glasgow, UK, 27-30 June, 2006,

Furbo S., A. Thür, F. Fiedler, C. Bales, J. Rekstad, M. Meir, D. Blumberga, C. Rochas and B. Karlsson, 2006, Nordic Energy Research Cooperation on Solar Combisystems, EuroSun Conference, Glasgow, UK, 27-30 June, 2006,

Jordan U. and K. Vajen, 2002, Influence of the DHW profile on the Fractional Energy Savings - A Case Study of a Solar Combisystem. Solar Energy. vol. 73, No.1, pp. 33-42.

Klein S. A., J. A. Duffie, J. C. Mitchell, J. P. Kummer, J. W. Thornton, W. A. Beckman, N. A. Duffie, J. E. Braun, R. E. Urban, N. J. Blair, D. E. Bradley, J. W. Mitchell, T. L. Freeman, B. L. Evans, A. Fiksel and P. M. Williams,2005, TRNSYS 16.0 Transient Simulation Program. SEL, University of Winsconsin, Madison, WI, USA.

Lorenz K. and C. Bales, 2003, Pellet Integral - Auxiliary Pellet Burner Integrated Into Solar Stores, ISES World Conference 2003, 2003. Gothenburg, Sweden, vol. 1.

METEONORM,1999, Weather Data Generator. METEOTEST. Bern, Switzerland.

Nordic-Ecolabelling, 2006a, About Swan-labelled Boilers for solid biofuel, Version 2.0, Background for ecolabelling.

Nordic-Ecolabelling, 2006b, Swan labelling of solid biofuel boilers. Version 1.5.

Nordlander S., 2003, TRNSYS model for Type 210, Pellet stove with liquid heat exchanger. SERC Report. Solar Energy Research Center, Högskolan Dalarna. ISRN DU-SERC--79--SE.

Nordlander S., T. Persson, F. Fiedler, M. Rönnelid and C. Bales, 2006, Computer modelling of wood pellet stoves and boilers connected to solar heating systems, Pellets 2006, 30 May - 1 June. Jönköping, Sweden,

Pelletcentre. http://www.pelletcentre.info/CMS/site.asp?p=3241, 23th of March, 2007. European Pellet Centre,

Persson T., 2004, Elbesparing i direktelvärmda hus med pelletkaminer och solvärme i direktvärmda småhus (Electrical savings by using wood pellet stoves and solar heating in single-family houses heated by electric resistance heating). Licentiate thesis. KTH. Stockholm, Sweden.

Persson T., 2006, Combined solar and pellet heating systems for single-family houses - How to achieve decreased electricity usage, increased system efficiency and increased solar gains. Doctoral Thesis. KTH - Royal Institute of Technology. Stockholm, Sweden.

Persson T., F. Fiedler and S. Nordlander, 2006a, Methodology for identifying parameters for the TRNSYS model Type $210-$ wood pellet stoves and boilers. SERC Report, ISRN DU-SERC--92--SE. Solar Energy Research Center, Högskolan Dalarna.

Persson T., F. Fiedler, M. Rönnelid and C. Bales, 2006b, Increasing efficiency and decreasing CO-emissions for a combined solar and wood pellet heating system for single-family houses, Pellets 2006 Conference, 30 May - 1 June. Jönköping, Sweden,

Persson T., S. Nordlander and M. Ronnelid, 2005, Electrical savings by use of wood pellet stoves and solar heating systems in electrically heated single-family houses. Energy \& Buildings 37, 9: 920-929.

Pettersson E., 2005, Förstudie: Provningssystem för småskalig biobränsle eldning. Energiteknisk Centrum i Piteå. ETC 2005-01.

RAL, 2003a, Der Blaue Engel, Grundlage für Umweltzeichenvergabe, Holzpelletheizkessel RAL-UZ 112. RAL Deutsches Institut für Gütesicherung und Kennzeichnung e.V.

RAL, 2003b, Der Blaue Engel, Grundlage für Umweltzeichenvergabe, Holzpelletöfen RAL-UZ 111. RAL Deutsches Institut für Gütesicherung und Kennzeichnung e.V.

SBBA. http://www.sbba.se/, 2005. SBBA - Swedish Heating Boilers and Burners Association.

SCB, 2005, Energistatistik för småhus 2004, EN 16 SM 0501. Statiskiska centralbyrån, SCB.

SCB, 2006, Housing and housing expenses in 2004. Statiskiska centralbyrån, SCB. BO 23 SM 0601.

SIS, 1999, Svensk Standard SS-EN 303-5, Värmepannor - Del 5: Värmepannor för fasta bränslen, manuellt och automatiskt matade. Swedish Standards Institut, SIS.

SP, 1999, SPs Certifieringsregler för P-märkning av Pelletsbrennare och Pelletspannor, SPCR 028. Sveriges Proviningsoch Forskningsinstitut, SP.

Streicher W. and R. Heimrath, 2003, Structure of the Reference Buildings of Task 26. IEA-SHC Task 26 Solar Combisystems.

Thür A., S. Furbo and L. J. Shah, 2004, Energy savings for solar heating systems, Eurosun 2004, Freiburg/Germany, pp. 715-724.

Weiss W. Solar Heating Systems for Houses - A Design Handbook for Solar Combisystems James \& James, 2003. 